\title{
Investigation of Aluminum Dross as a Potential Asphalt Filler
}

\author{
B. UdVARDI ${ }^{1}$, R. GÉBER ${ }^{2}$, I. KOCSERHA ${ }^{3}$ \\ ${ }^{1}$ University of Miskolc, Faculty of Material Science, Institute of Ceramics and Polymer Engineering, \\ ubella07@gmail.com, \\ ${ }^{2}$ University of Miskolc, Faculty of Material Science, Institute of Ceramics and Polymer Engineering, \\ robert.geber@uni-miskolc.hu, \\ ${ }^{3}$ University of Miskolc, Faculty of Material Science, Institute of Ceramics and Polymer Engineering, \\ istvan.kocserha@uni-miskolc.hu
}

Abstract. There is a great concern about utilizing different waste materials all over the world. Stockpiling in landfills is not a final solution, therefore researchers try to find alternative methods to utilize these materials [1-5]. One potential area may be road construction. Fillers are one of the most important components of asphalt pavements. It has a dual role. First of all, these fine grained mineral materials $(d<0.063 \mathrm{~mm})$ enhance the cohesion with bitumen. Second is to fill the gaps between the particles to produce more compact mixture [6]. The aim of this research is to reveal the possibility of utilization of aluminum dross as a potential asphalt filler. This material, which is a by-product of aluminum casting process, is produced in large quantities year by year and its storage in landfills is not a proper solution. Therefore, there is an increasing demand to utilize this material. During the research material structural tests were made, which can characterize the samples (limestone powder, dross), and the cohesion between bitumen and filler can also reveal. Particle size distribution, BET specific surface area and porosity were investigated. Scanning electron micrographs were taken and oil adsorption test were also made.

\section{Introduction}

Waste materials are produced year by year all over the world. Handling and storage of these materials are not solved, so it causes large problem for the environment and also from an economic point of view. So this is the reason that in the asphalt technology and many industrial sector constant searching needed for alternative materials and possibilities to apply recycled and processed waste materials. On the other hand when alternative materials is used, the amount of yielded mineral raw materials can decrease.

Aluminum dross is a by-product of the melting process of aluminum. Two types of dross are generated during primary and secondary aluminum production, which can be sorted according to their metal content:

- white (or non- salt containing) dross,

- black (or salt containing) dross. 
White dross is stemmed from the primary aluminum refining process, and this material has got higher metallic aluminum content. Black dross is formed during the secondary aluminum casting, which has a lower metallic Aluminum content, than white dross [7, 8, 9, 10, 11, 12]. In this research work the black dross is tried to utilize as a potential asphalt filler. Limestone is the most frequently used mineral material, especially as filler in the road construction. This mineral material can create a good connection with the binder (bitumen). The most important properties of asphalt mixtures are determined by the quality of the aggregates and the type and quality of the binder. Different additives, like cellulose-based materials (for example VIATOP products) are also used to improve performance of asphalt pavement [13].

During the research different material structural tests were made. Particle size distribution, BET specific surface area and porosity were determined on these raw materials. For microstructural observation scanning electron micrographs were taken and oil adsorption test (so-called German Filler Test) were also made.

\section{Sample preparation}

Aluminum dross was crushed by hammer and comminuted by planetary ball mill. Limestone was in a bulk state as-received from the manufacturer. Using standard sieves, the required particle size $(\mathrm{d}<0.063 \mathrm{~mm})$ was prepared. Laboratory drying chamber was used to dry the mineral materials for weight-constancy.

\section{Results and discussion}

\subsection{Chemical element composition and microstructure}

One of the main roles of fine grain fillers is to increase the mechanical strength and stiffness of the asphalt pavement. Strength can be improved by increasing the cohesion between mineral materials and bitumen, therefore it is important to explore the material structure and composition.

\begin{tabular}{|c|c|c|}
\hline Chemical element & Limestone [wt $\%]$ & Aluminum dross [wt $\%]$ \\
\hline $\mathrm{C}$ & 9.20 & 0.00 \\
\hline $\mathrm{O}$ & 37.34 & 18.13 \\
\hline $\mathrm{Mg}$ & 0.49 & 2.90 \\
\hline $\mathrm{Al}$ & 0.87 & 31.8 \\
\hline $\mathrm{Si}$ & 2.08 & 1.31 \\
\hline $\mathrm{Ca}$ & 49.59 & 3.32 \\
\hline $\mathrm{Na}$ & 0.00 & 10.39 \\
\hline $\mathrm{Cl}$ & 0.00 & 25.82 \\
\hline $\mathrm{K}$ & 0.45 & 5.79 \\
\hline Total & 100.02 & 99.46 \\
\hline
\end{tabular}

Table 1. Chemical composition of fillers

Chemical element composition was determined on the fillers by energy dispersive X-ray spectroscopy. The results are shown in Table 1 . The results show that both fillers contain $\mathrm{O}, \mathrm{Mg}, \mathrm{Al}, \mathrm{Si}, \mathrm{Ca}, \mathrm{K}$ elements, 
but these are in different quantities. Dross contains aluminum metal in high amount. It can be stated that dross still contains aluminum obtained from other production method. $\mathrm{Na}, \mathrm{Cl}$ and $\mathrm{K}$ elements are in significant quantities, which indicate the presence of slag-forming agents $(\mathrm{NaCl}, \mathrm{KCl})$.

The shape of the mineral materials used in the asphalt mixture affects the internal friction of mineral skeleton and the bearing capacity of the asphalt pavement. The spherical, rounded particles can reduce, while long-shaped, drawling particles can be increase internal friction. Scanning electron micrographs (SEM) were taken to observe the microstructure and surface features of fillers. Fig. 1. illustrates that the tested fillers have similar geometrical features. The shape of the particles are varied. Particle size distribution can visualize on the micrographs, as well.

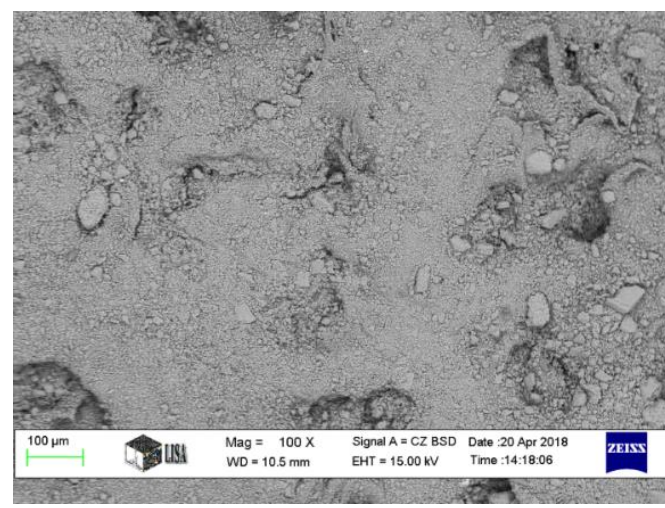

Limestone powder

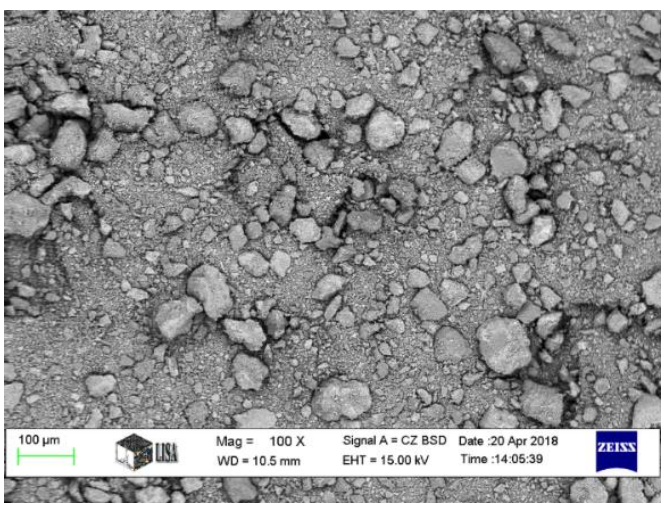

Aluminum dross

Figure 1. SEM photos of the fillers

\subsection{Particle size distribution}

Particle size distribution of fillers have an important role in asphalt technology. Particle size and distribution of fillers effect on the viscosity of the binder and hence the stiffness of the asphalt pavement. Fillers affects also the adsorption capacity of binder, so this examination is very relevant.

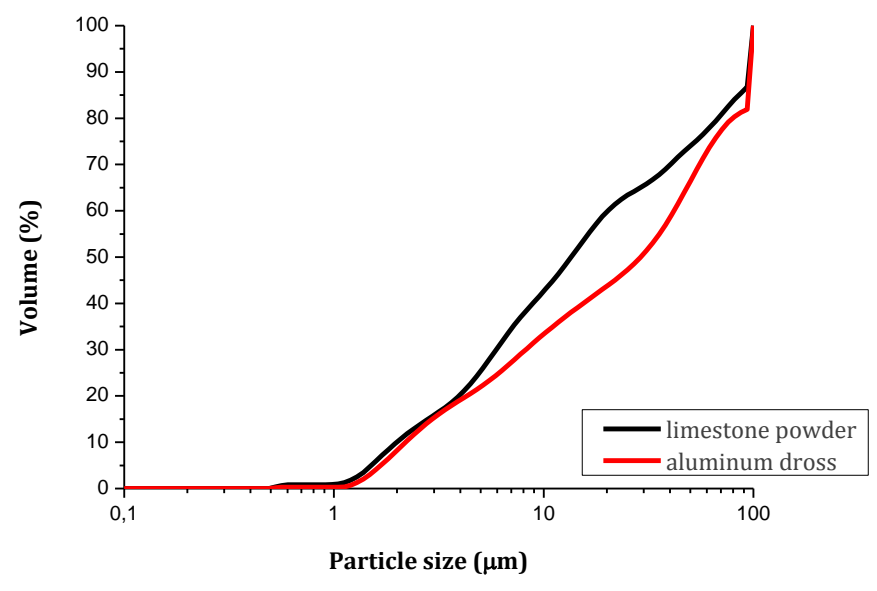

Figure 2. Particle size distribution of fillers 
Particle size distribution tests were made using Malvern Mastersizer X type particle size analyzer. Gradation of fillers are presented in Fig. 2. According to the results, there is no significant difference between the particles size of fillers. The figure represents that limestone contains finer particles, than aluminum dross. It can be shown also on the SEM micrographs in Fig. 1. The gradation curves show that both fillers of particle size are characteristically under $10 \mu \mathrm{m}$ in the particle size ranges.

\begin{tabular}{|c|c|c|}
\hline Test & Limestone powder & Aluminum dross \\
\hline Average particle size, $\mathrm{d}_{50}$ & 13.77 & 15.62 \\
\hline
\end{tabular}

Table 2. Average particle size of fillers

Table 2. presents information about the average particle size. As it can be seen average particle size of the limestone powder is under $14 \mu \mathrm{m}$, while the dross is under $16 \mu \mathrm{m}$. Polydispersity of fillers provides a good packing, which enables high compactness and strength in the asphalt mixture. Fillers with finer particles are expected to increase the stiffness effect of the mixture.

\subsection{BET specific surface area and BJH porosity}

As the interaction between bitumen and mineral materials depends on the adsorption processes at their interface, the determination of specific surface area is very important. BET specific surface area were determined by $\mathrm{N} 2$ adsorption method. The test is important, because the mineral materials with high specific surface area require bitumen surpluses, which can reduce the strength and stiffness of the asphalt pavement over a certain limit. Bitumen surplus is economically disadvantageous.

\begin{tabular}{|c|c|c|c|}
\hline Parameters & Unit & Limestone powder & Aluminum dross \\
\hline $\begin{array}{c}\text { BET specific surface } \\
\text { area (SSA) }\end{array}$ & $\mathrm{m}^{2} / \mathrm{g}$ & 1.55 & 1.26 \\
\hline $\begin{array}{c}\text { BJH desorption average } \\
\text { pore diameter }\end{array}$ & $\mathrm{nm}$ & 27.64 & 30.05 \\
\hline $\begin{array}{c}\text { BJH desorption } \\
\text { cumulative pore } \\
\text { volume of pores }\end{array}$ & $\mathrm{cm}^{3} / \mathrm{g}$ & 0.006675 & 0.009535 \\
\hline $\begin{array}{c}\text { BJH desorption } \\
\text { cumulative surface area } \\
\text { of pores }\end{array}$ & $\mathrm{m}^{2} / \mathrm{g}$ & 0.9661 & 1.1017 \\
\hline
\end{tabular}

Table 3. Results of the specific surface area and the porosity

Table 3. illustrates the results of the BET specific surface area and porosity. Specific surface area of the limestone powder is slightly higher, than the dross. The reason for this is due to the particle size, because limestone consists finer particles. In the case of aluminum dross, particle size is coarser, which indicates a reduction in the specific surface area.

Using $\mathrm{N}_{2}$ adsorption pore size distributions can be determined using Barett-Joyner-Halenda (BJH) method in a nanometric scale (in the range of 1.7 to $300 \mathrm{~nm}$ ). Average pore diameters are almost the same (limestone: $27.64 \mathrm{~nm}$, dross: $30.05 \mathrm{~nm}$ ), which is favourable for the utilization aspects. 


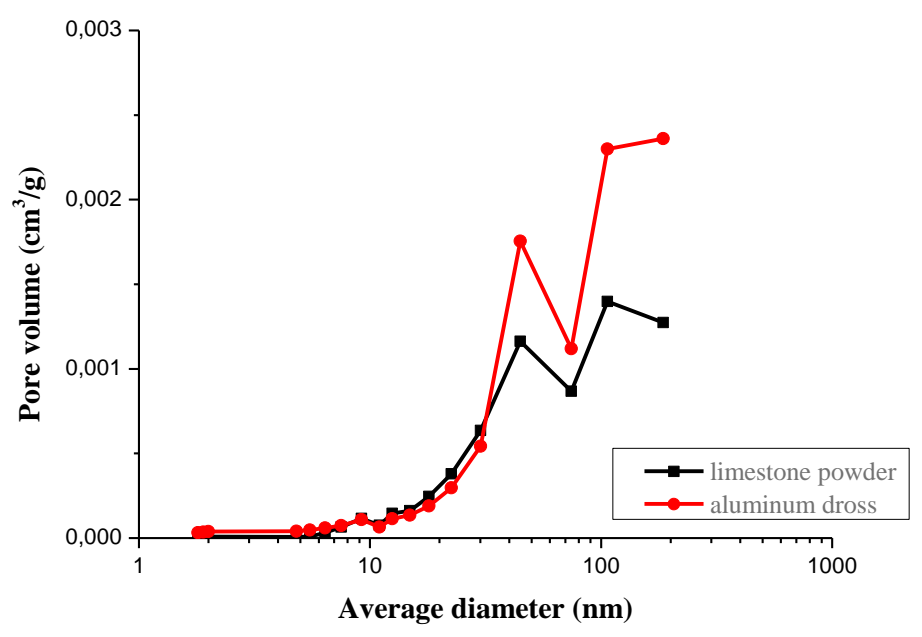

Figure 3. BJH porosity of fillers

The graph shows that both materials contain almost equal pore volume under $10 \mathrm{~nm}$, however there is a difference in the higher pore diameter ranges. According to the results, dross has a higher average pore diameter and a higher volume of pores.

\subsection{The oil adsorption capacity of fillers (German Fillers Test)}

German Filler Test is an examination to reveal the oil adsorption capacity of fillers. This measurement is not standardized, but very useful in practice. This test was developed by the German Koch Materials Company, and indicates the cohesion between and filler. The method was based on that oil fills the interparticle voids. The method is the following (Fig. 4.):
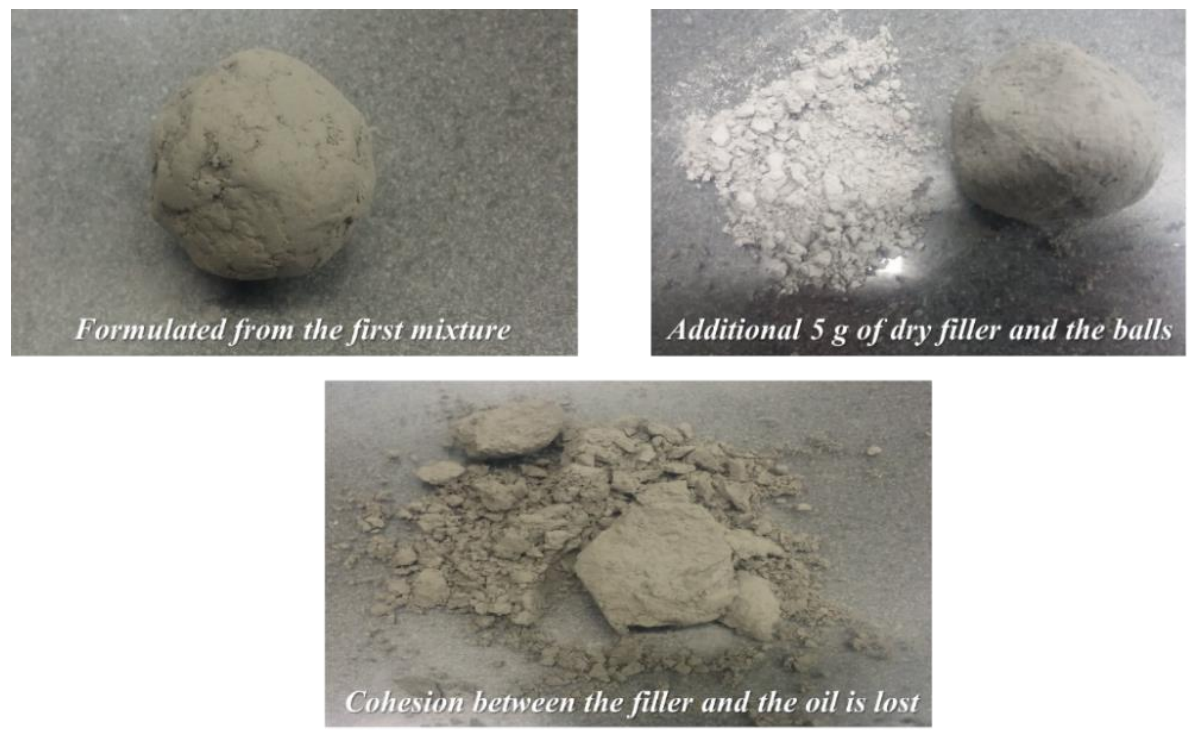

Figure 4. Step of the German Filler Test

15 grams of hydraulic oil was added to $45 \mathrm{~g}$ of dry filler and mixed together. From this mixture a ball is required to form. After that, another 5 grams of filler was added to the mixture and was well kneaded. 
This step was repeated until cohesion between filler and oil was lost the amount of dry material is recorded [6].

\begin{tabular}{|c|c|c|}
\hline Fillers & Limestone powder & Aluminum dross \\
\hline Amount of dry materials $[\mathrm{g}]$ & 50 & 45 \\
\hline
\end{tabular}

Table 4. Results of German Filler Test

Dross has lower value than limestone, but this difference is not relevant. This test method depends on the voids, particle size and shape, and the particle size distribution. Considering the specific surface area, it can be stated that those materials, which have a higher specific surface area are able to adsorb more oil.

\section{Conclusion}

During the research work aluminum dross was investigated as a potential asphalt filler. According to the chemical element composition aluminum dross was more complicated material, than the reference mineral material. Particle size distribution of fillers are similar, however limestone powder contains finer particles, which results higher specific surface area, as well. According to the morphological tests it can be stated that these fillers are applicable in asphalt mixtures. Results of the German Filler Test pointed out that aluminum dross has lower oil adsorption capacity, than limestone, but this difference is not significant.

Based on the results dross may be a potential asphalt filler to substitute limestone powder. However, further investigation and standard asphalt tests are needed to determine the exact amount of dross used in asphalt mixtures.

\section{Acknowledgement}

Present research is a part of GINOP -2.2.1-15-201600018 project.

\section{References}

[1] R.K. Dhir - L.J.Csetenyi - T.D. Dyer - G.W. Smith (2010) Cleaned oil-drill cuttings for use as filler in bituminous mixtures. Construction and Building Materials. 24 (3) pp. 322-325.

[2] C. Gürer - G.Ș. Selman (2016) Investigation of Properties of Asphalt Concrete Containing Boron Waste as Mineral Filler. Materials Science (Medziagotyra). 22 (1) pp. 118-125.

[3] M. S. Reddy - D. Neeraja (2016) Mechanical and durability aspects of concrete incorporating secondary aluminum slag. Resource-Efficient Technologies. 2 (4) pp. 225-232.

[4] M. Chen - J. Lin - S. Wu - C. Liu (2011) Utilization of recycled brick powder as alternative filler in asphalt mixture. Construction and Building Materials. 25 (4) pp. 1532-1536.

[5] S. Wu - J. Zhu - J. Zhong - D. Wang (211) Experimental investigation on related properties of asphalt mastic containing recycled red brick powder. Construction and Building Materials. 25 (6) pp. 2883-2887. 
[6] P. S. Kandhal - C. Y. Lynn - F. Parker, Jr. (1998) Characterization tests for mineral fillers related to performance of asphalt paving mixtures. National Center for Asphalt Technology Report. 1638 pp. 101-110.

[7] G.J. Kulik - J.C. Daley (1990) Aluminum Dross Processing in the 90's. The Minerals, Metals \& Materials Society-AIME,. pp. 427-437.

[8] R.D. Peterson - L. Newton (2002) Review of Aluminum Dross Processing. The Minerals, Metals \& Materials Society -AIME. pp. 1029-1038.

[9] L.S. Carvalho (1991) Estado da arte da tecnologia do tratamento de escória na indústria do alumínio. In: III Seminário de Tecnologia da Indústria do alumínio. pp. 169-192.

[10] D.S. Gwinner (1996) Environmental Issues in the Aluminum Reclamation Industry. Associação Brasileira do Alumínio,. pp. 40-51.

[11] E. Petavratzi - S. Wilson (2007) Residues from Aluminum dross recycling in cement, Case study, pp. 1-8.

[12] J.Y. Hwang - X. Huang - Z. Xu (2006) Recovery of Metals from Aluminum Dross and Salt cake. Journal of Minerals \& Materials Characterization \& Engineering. 5 (01) pp. 47-62.

[13] Cs. Tóth - Z. Soós (2015) The effect of VIATOP ® plus FEP on the stiffness and low temperature behaviour of hot mix asphalts. Journal of Silicate Based and Composite Materials. 67 (4) pp. 126131. 